\title{
The Measurement of Social Desirability and Brand Equity in Emerging Societies
}

\author{
B. P. Suresh \\ Himadri Roy Chaudhuri \\ XLRI \\ Jie G. Fowler \\ Valdosta State University \\ Timothy H. Reisenwitz \\ Valdosta State University
}

This study attempted to develop the consumer-based brand equity (CBBE) measure by including social responsibility as an additional dimension in India. Five hypotheses were proposed based upon the literature review and included the following variables: brand awareness, brand association, perceived quality, brand loyalty, and social responsibility. All hypotheses were supported. This study developed a new brand equity measurement and provides empirical evidence of the multidimensionality of CBBE.

Keywords: socially responsible brands, consumer-based brand equity, brand awareness, brand associations, perceived quality, brand loyalty, and social responsibility

\section{INTRODUCTION}

The Edelman's Good Purpose 4th Annual Study (2010) reports that 90 percent of Indian consumers prefer buying socially responsible brands. Specifically, 84 percent said they would remain loyal to such brands; 88 percent are willing to pay the premium for products that are environmentally friendly; and 93 percent believe that business should place emphasis on society's interests.

That being said, Kotler (2007) states buyers favor firms that manifest social responsibility and earn a reputation as good citizens. Socially conscious consumers are defined as individuals who believe that their purchases will make a positive impact on society and as such, they would purchase the brands which take up such activities. Bedall (2011) says the mindset is, why not do some good and make a contribution while enjoying your shopping.

Koçak, Abimbola, and Ozer (2007) further demonstrate that studies in different contexts are vital to ensure external validity and suggest consumers may arrive at different evaluations of brands as a result of different cultural conditions. Christodoulides and de Chernatony (2010) propose that researchers may look into the conceptual and metric equivalence of brand equity, such as in individualism/collectivism 
dyads. There are significant differences in Indian customers compared to the West regarding economic condition, social atmosphere, and culture. Thus, it is essential to examine existing consumer-based brand equity (CBBE) measurement in emerging markets. Therefore, the ultimate goal of the study is to develop the $\mathrm{CBBE}$ measurement by including the social responsibility as an additional dimension in India.

\section{Research Context}

The basic aspect of branding is its power to provide distinctive reasons for customers to prefer one brand over another and reflect the complete experience that customers have with their products. Intangibles cover a wide range of different types of brand associations, such as actual/aspirational imagery, purchase patterns, and heritage (Keller, 2001). Marketers then argue that while brands have value to various constituencies, it is the consumer who first determines brand equity (Farquhar, 1989; Crimmins, 1992). Berthon et al. (2001) further state scholars have not reached an agreement of how to measure brand equity (see Table 1).

TABLE 1

\section{VARIOUS DEFINITIONS OF CBBE AS PRESENTED BY THE RESPECTIVE ACADEMICIAN(S)}

\begin{tabular}{|c|c|}
\hline Author(s) & Definition \\
\hline Farquhar (1989) & The added value with which a given brand endows a product. \\
\hline Kamakura \& Russell (1991) & $\begin{array}{l}\text { The perceived brand quality of both the brand's tangible and } \\
\text { intangible components. }\end{array}$ \\
\hline Aaker (1991) & $\begin{array}{l}\text { A set of brand assets and liabilities linked to a brand, its name } \\
\text { and symbol that add to or subtract from the value provided by a } \\
\text { product or service to a firm and/or to that firm's customers. }\end{array}$ \\
\hline Srivastava \& Shocker (1991) & $\begin{array}{l}\text { A set of memories in the extended minds of a brand's customers, } \\
\text { distribution channel members, parent company, and other key } \\
\text { members of its network that will impact future cash-flow. }\end{array}$ \\
\hline Simon \& Sullivan (1993) & $\begin{array}{l}\text { The incremental cash flows that accrue to the firm due to its } \\
\text { investment in brands. }\end{array}$ \\
\hline $\begin{array}{l}\text { Swait, Erdem, Louviere \& } \\
\text { Dubelaar (1993) }\end{array}$ & $\begin{array}{l}\text { The monetary equivalent of the total utility a consumer attaches } \\
\text { to a brand. }\end{array}$ \\
\hline Keller (1993) & $\begin{array}{l}\text { The differential effect that brand knowledge has on consumer } \\
\text { response to the marketing of that brand. }\end{array}$ \\
\hline Park \& Srinivasan (1994) & $\begin{array}{l}\text { The incremental preference endowed by the brand to the product } \\
\text { as perceived by an individual consumer. }\end{array}$ \\
\hline de Chernatony \& McDonald (1996) & $\begin{array}{l}\text { The differential attributes underpinning a brand which give } \\
\text { increased value to the firm's balance sheet. }\end{array}$ \\
\hline Erdem \& Swait (1998) & Value of a brand signal to consumers. \\
\hline Mitra \& Ghosh (2007) & $\begin{array}{l}\text { Represents the sum total of all different values which the people } \\
\text { attach to that brand. }\end{array}$ \\
\hline
\end{tabular}


Current knowledge of brand equity has evolved from two theoretical approaches: cognitive psychology and signaling theory in information economics. Cogitive psychology focuses on memory structure (Aaker, 1991, 1996; Keller, 1993; Farquhar, 1989; and Mitchell \& Dacin, 1996), and memory can be explained with a commonly used psychological model known as an associative network memory model (Anderson, 1993; Wyer \& Srull, 1989). According to this theory, an individual's knowledge of a brand is depicted as brand knowledge, which consists of a brand node and a number of associations linked to it (Farquhar, 1989; Aaker, 1991; Keller, 1993, 1998; Mitchell \& Dacin, 1996).

Brand equity research is also rooted in information economics and considers the imperfect and asymmetrical nature of contemporary markets. Erdem and Swait (1998) point out that economic agents transmit information by means of signals and brand names may act as such signals to consumers. Imperfect and asymmetrical market information creates uncertainty in consumers' minds. A credible brand signal can generate customer value by reducing perceived risk, reducing information search costs, and creating favorable attribute perceptions. Brand equity can therefore be analyzed on two levelsconsumer or firm level, depending on the beneficiary of value. Marketing research has concentrated on CBBE as opposed to firm-based brand equity (Keller, 1993).

\section{Consumer-Based Brand Equity}

Leuthesser, Kohli, and Harich (1995) point out that consumers are predisposed towards the brand they aware. During the evaluation of attributes, this predisposition is manifest through the statistical "halo effect" (or error). Shankar, Azar and Fuller (2008) observe that consumer surveys can capture the drivers of brand image such as brand reputation, brand uniqueness, brand fit and brand fame. The advantages of their method are in estimating brand equity of multi-category brands and beneficial in terms of combining both financial and consumer data (see Table 2).

TABLE 2

BRAND EQUITY AND THE RELATED CONSTRUCTS

\begin{tabular}{|c|c|c|c|c|c|c|}
\hline Components of CBBE & $\begin{array}{c}\text { Aaker } \\
(1991,1996)\end{array}$ & $\begin{array}{l}\text { Keller } \\
(1993)\end{array}$ & $\begin{array}{l}\text { Sharp } \\
(1995)\end{array}$ & $\begin{array}{l}\text { Aaker } \\
\text { (1997) }\end{array}$ & $\begin{array}{c}\text { Fournier } \\
\text { (1998) }\end{array}$ & $\begin{array}{l}\text { Berry } \\
(2000)\end{array}$ \\
\hline Brand Awareness & $\sqrt{ }$ & $\sqrt{ }$ & $\sqrt{ }$ & & & \\
\hline Brand Associations & $\sqrt{ }$ & $\sqrt{ }$ & & & & \\
\hline Perceived Quality & $\sqrt{ }$ & & & & & $=$ \\
\hline Brand Loyalty & $\sqrt{ }$ & & & & & \\
\hline Brand Image & & & $\sqrt{ }$ & & & $=$ \\
\hline Relationship with customers & & & $\sqrt{ }$ & & $\sqrt{ }$ & \\
\hline Brand Personality & & & & $\sqrt{ }$ & & \\
\hline Brand Meaning & & & & & & $\sqrt{ }$ \\
\hline
\end{tabular}


Compared to approach stated previously, others adopt a more holistic view of the brand. The review of literature was able to identify 29 empirical studies using indirect approaches to capture CBBE at the individual level (see Table 3). Agarwal and Rao (1996) and Mackay (2001) also list a variety of components that characterize brand equity (see Table 4).

TABLE 3

\section{CONSUMER-BASED BRAND EQUITY STUDIES}

\begin{tabular}{|c|c|c|c|c|}
\hline Sl. & Authors & Year & & Product category \\
\hline 1 & Cobb-Walgren et al. & 1995 & USA & hotels, cleansers \\
\hline 2 & Lassar et al. & 1995 & USA & television (TV), watches \\
\hline 3 & Agarwal \& Rao & 1996 & USA & Candies \\
\hline 4 & Yoo et al. & 2000 & USA & athletic shoes, camera film, colour TV sets \\
\hline 5 & Yoo \& Donthu & 2001 & USA \& Korea & athletic shoes, camera film, colour TV sets \\
\hline 6 & Washburn & 2002 & USA & crisps, paper towels \\
\hline 7 & Vacquez et al. & 2002 & Spain & sports shoes \\
\hline 8 & Netemeyer et al. & 2004 & USA & colas, toothpaste, athletic shoes, jeans \\
\hline 9 & Punj & 2004 & USA & soap and toothpaste \\
\hline 10 & Washburn & 2004 & USA & paper towels, disinfectant \\
\hline 11 & de Chernatony & 2004 & UK & financial services \\
\hline 12 & Hsieh & 2004 & 20 countries & cars \\
\hline 13 & Bauer et al. & 2005 & Germany & team sport \\
\hline 14 & Paapu et al. & 2005 & Australia & cars, television \\
\hline 15 & Srinivasan \& Park & 2005 & South Korea & mobile service \\
\hline 16 & Vera & 2006 & Mexico & brasseries, lotion, bottled water \\
\hline 17 & Christodolouides & 2006 & UK & E tailers \\
\hline 18 & Kayaman \& Arasali & 2007 & Cyprus & five-star hotels \\
\hline 19 & Kocak et al. & 2007 & Turkey & sports shoes \\
\hline 20 & Taylor et al. & 2007 & USA & financial services \\
\hline 21 & Kim et al. & 2008 & S.Korea & luxury hotels \\
\hline 22 & Buil et al. & 2008 & UK, Spain & soft drinks, sportswear, electronics, cars \\
\hline 23 & Rajashekar \&Nalina & 2008 & India & consumer durables \\
\hline 24 & Yang et al. & 2008 & Taiwan & fast food service \\
\hline 25 & Jensen \& Klastrup & 2008 & Sweden & Industrial pumps (B2B market) \\
\hline 26 & Sinha et al. & 2008 & New Zealand & electronic goods \\
\hline 27 & Nel \& North & 2009 & S. Africa & hotels \\
\hline 28 & Tong \& Hawley & 2009 & China & sportswear \\
\hline 29 & Atilgan et al. & 2009 & USA, Turkey Russia & soft drinks, fast food restaurants \\
\hline
\end{tabular}




\section{TABLE 4}

\section{COMPONENTS OF CBBE CAPTURED BY EMPIRICAL STUDIES}

\begin{tabular}{|c|c|c|c|}
\hline S1.No & Components & $\begin{array}{l}\text { Grouped components } \\
\text { similar meaning }\end{array}$ & $\begin{array}{c}\text { Number of empirical studies } \\
\text { using the constructs }\end{array}$ \\
\hline 1 & Perceived Quality & 7 & 28 \\
\hline 2 & User Satisfaction/Loyalty & 6 & 25 \\
\hline 3 & Awareness & 2 & 18 \\
\hline \multirow[t]{7}{*}{4} & Associations & & \\
\hline & Brand Relationship & 9 & 15 \\
\hline & Perceived Value & 7 & 13 \\
\hline & Organizational Associations & 3 & 12 \\
\hline & Differentiation & 4 & 7 \\
\hline & Brand Trust & 3 & 7 \\
\hline & Personality & 1 & 2 \\
\hline 5 & Price Premium & 2 & 6 \\
\hline 6 & Leadership & 2 & 3 \\
\hline
\end{tabular}

Note: Brand Associations, i.e., Brand Relationship, Perceived Value, Organizational Associations, Differentiation, Brand Trust, and Personality are all pooled under the component of Association

A majority of studies (12) are from the United States, and the remaining (17) were from a variety of countries. Kocak, Abimbola, and Ozer (2007) replicate the study of Vazquez et al. (2002) in Turkey to ascertain whether their scale could be applied to a different cultural context. Their results showed that the original 22-item scale developed by Vazquez et al. (2002) in Spain was not appropriate for a Turkish sample. Therefore, Kocak et al. (2007) conclude that the differences between the original and replication study may be due to cultural differences. As such, this study aims to examine brand equity measurement by including social responsibility as an additional dimension in India.

\section{Hypotheses}

The components of CBBE captured by 29 empirical studies are listed in Table 4. The mainly used components were Brand Awareness, Brand Associations, Perceived Quality, Brand Loyalty. As such, these measures are adapted in this study. This selection is also consistent with Adker $(1991 ; 1996)$ study.

\section{Brand Awareness}

Brand awareness can be characterized by depth and breadth. The depth of brand awareness relates to the likelihood that the brand can be recognized or recalled. The breadth of brand awareness relates to the variety of purchase and consumption situations in which the brand comes to mind. Brand awareness influences a customer's decision making by determining the order and strength of associations with the brand image, and together brand image and brand awareness form the customer's knowledge of the brand (Keller, 1993). Aaker (1996a) and Yoo et al. (2000) point out that brand awareness reflects the prominent attributes of the brand in the mind of the customer; it influences customers' perceptions and attitudes 
towards a brand. In some situations, it can drive brand choice and loyalty. Thus, the following hypothesis is posited.

H1: The higher (lower) the level of brand awareness, the more positive (negative) the brand equity in consumers' minds.

\section{Brand Association}

Brand associations create value for the firm and its customers by helping to process/retrieve information, differentiate the brand, create positive attitudes/feelings, provide a reason to buy, and offer a basis for extensions (Aaker, 1991; Low \& Lamb, 2000; Yoo et al., 2000). They are believed to contain the meaning of the brand for consumers. Brand association can be seen in all forms and reflects features of the product or aspects independent of the product itself (Chen, 2001). According to Keller (1993), brand association consists of three sub-components in consumer memories: strong, favorable, and unique brand associations. Associations increase in strength when based on more experiences and exposure to communications of the brand and will assist in customer decision making (Yoo et al., 2000). Pappu et al. (2005) suggest researchers should incorporate items related to these types of associations in their measurement. Hence, the following hypothesis is proposed.

H2: The more positive (negative), stronger (weaker) the brand association, the more positive (negative) the brand equity in consumers' minds.

\section{Perceived Quality}

Perceived quality is the primary facet across the CBBE framework (Aaker, 1996; Farquhar, 1989). Perceived quality is defined as the customer's perception of the overall quality or superiority of a product or service with respect to its intended purpose, relative to alternatives (Aaker, 1991; Zeithaml, 1988). Therefore, brand equity will increase when customers perceive brand quality (Yoo et al., 2000). Much research has been done on health and product safety with regard to food (e.g., Brunso, Thomas, \& Grunert, 2002; Ophuis \& Van Trijp, 1995; Torjusen, Lieblein, Wandel, \& Francis, 2001). Kotler (1991) points out the intimate connection among product and service quality, customer satisfaction, and company profitability. Based on this, the following hypothesis is posited.

H3: The higher (lower) the level of perceived quality, the more positive (negative) the brand equity in consumers' minds.

\section{Brand Loyalty}

Brand loyalty is defined as the tendency to be loyal to a focal brand as demonstrated by the intention to buy it as a primary choice (Yoo \& Donthu, 2001). From a behavioral perspective, Oliver $(1997,392)$ defines brand loyalty as, "a deeply held commitment to repeat buying/patronizing a preferred product or service consistently in the future, despite situational influences and marketing efforts having potential to cause switching behavior." Further, Schoell and Guiltinan (1990) see brand loyalty as the degree to which a buying unit, such as a household, concentrates its purchases over time on a particular brand within a product category (Schoell \& Guiltinan, 1990). Loyal customers are less likely to switch to a competitor solely because of price; they also make more frequent purchases compared to disloyal customers (Bowen and Shoemaker, 1998; Yoo et al., 2000). Brand equity may increase to the extent that a customer becomes brand loyal. Based on this, the following hypothesis is posited.

H4: The higher (lower) the level of brand loyalty, more positive (negative) the brand equity in consumers' minds. 


\section{Perceived Social Responsibility}

Pizzolatto and Zeringue (1993) propose three levels of corporate social concern based on the organization's assertiveness in their action. The first is social obligation, a business obeying the laws of the state. The second is social responsiveness, a business taking on activities because of public demand, such as recycling, waste reduction, the use of environmentally friendly products, etc. The third is social responsibility, an organization going beyond its business by taking up activities to improve the lives of people and protecting the environment. Studies have focused on the integration of social actions and marketing strategies that have revealed the impact of these variables on the competitiveness of firms in markets (Archibald et al., 1990; Barone et al., 2000). For instance, Madrigal (2000) observes that corporate social responsibility (CSR) affects judgments of specific product attributes. According to Varadarajan and Menon (1988), cause-related marketing aims to enhance company revenues and sales through product differentiation by creating socially responsible attributes associated with brands. In addition, the brand evokes positive or negative feelings, especially in the context of sensitive social and ecological issues (Bartels \& Nelissen, 2002). Based on the previous discussion, the following hypothesis is posited.

H5: The higher (lower) the consumer perceptions of socially responsible activities of the organization, the more positive (negative) the brand equity in consumers' minds.

\section{Rewarding Socially Responsible Brands}

Keller (1993) believes that a thorough understanding of CBBE is essential for successful brand management since the context and structure of memory for the brand will influence the effectiveness of future brand strategies. Previous studies report a positive impact of organizations' socially-responsible activities with consumer goodwill (Murray \& Vogel, 1997; Sen, 1993), positive influence on consumers' buying intentions (Brown \& Dacin, 1997; Creyer \& Ross, 1997), and willingness to pay a higher price for products made by a socially-responsible firm (e.g., De Pelsmacker, Driesen \& Rayp, 2005; Polonsky, Brito, Pinto \& Higgs-Kleyn, 2001). Based on the above discussion, the following hypothesis is posited.

H6: The higher (lower) the level of consumer-based brand equity, the more positive (negative) the intention to reward a socially responsible brand.

\section{METHOD}

The research was in three phases; the first phase was an extensive literature review to identify the items used in capturing the following components: brand awareness, brand association, perceived quality and brand loyalty. In the second phase, an exploratory survey was conducted, and in the last phase, the confirmatory study was applied to this study. The study followed the scaling procedure recommended in the literature (e.g., Churchill, 1979; Netemeyer et al., 2003, Nunnally \& Bernstein, 1994) (see Table 5).

Clark and Watson (1995) advocate to generate a large number of items to ensure a sufficient breadth of content and an adequate pool of items within each theoretical component. The initial survey instrument was developed by incorporating a pool of 88 items compiled from the literature: 13 items for brand awareness, 18 items for brand association, 21 items for perceived quality, and 21 items on brand loyalty. Items for these four dimensions were taken from established scales. In case of perceived social responsibility, the construct had 15 items. 
TABLE 5

ITEMS OF CBBE COMPONENTS

\begin{tabular}{ccc}
\hline Component & Items generated & Items after initial purification \\
\hline Awareness & 13 & 9 \\
Association & 18 & 14 \\
Perceived Quality & 21 & 8 \\
Brand Loyalty & 21 & 12 \\
Perceived Social Resp & 15 & 9 \\
Total & 88 & 52 \\
\hline
\end{tabular}

Initially, we identified the consultant/managers in the area of branding and brand management to check for the relevance of the items. A total of 62 experts were identified. The experts ranked the items in terms of their relevance to that particular construct. The pilot study was administered to 110 postgraduate students. The questionnaire was developed with a five-point Likert scale, where one on the scale indicated strongly disagree and five indicated strongly agree with three as a neutral point, neither agree nor disagree. Based on the feedback of the pilot study, the wording of a few items was modified, and eight items were deleted from the initial scale. A questionnaire to 200 consumers was then administered. Exploratory factor analysis was applied to check the internal consistency of the items.

Finally, a main study questionnaire of 1,200 consumers was administered. Following similar studies (Pappu et al., 2005) using multiple measures to capture brand constructs, this study used measures on a five-point scale. Two different versions of the questionnaire were used, one for each of the product categories. The questionnaire containing 52 items was used for a pilot study representing the constructs of interest: brand awareness, brand associations, perceived quality, brand loyalty, perceived social responsibility of the brand, and rewarding socially responsible brands. An attempt was made in the study to capture socially conscious consumers. Apart from the items, the questionnaire included demographic details and the usage of the brands.

The study attempted to apply product categories to the conceptualization of CBBE. The product categories identified were dairy products and snack products. The two categories were selected based upon the purchase frequency and familiarity of the respondents and brands from different formats of organization. The focal construct of the research is CBBE, which is a brand-level construct, thus brand is the unit of analysis and the sampling unit is individual consumers. The brands identified in dairy products were Nandini, Heritage and Nestle and the brands identified in snacks were Lijjat, Haldirams and Lays. The items were analyzed through confirmatory factor analysis (CFA).

\section{RESULTS}

A total of 15 items was shortlisted after the pilot testing and expert opinion survey. To check whether the scale was internally consistent, the coefficient alphas were computed for the overall CBBE scale and its five subscales. The items are listed in Table 6. The composite CBBE scale and all its subscales achieved coefficient alpha values greater than 0.70 , which are indicative of internal consistency (Nunnally, 1978). As the purpose of the study was to build an exploratory scale, the psychometric properties of the SCC scale were found to be adequate. Finally, dropping three items, a 12-item scale was found to be adequate and retained for the preliminary SCC scale (see Table 7). 
TABLE 6

RELIABILITY OF CBBE SCALE

\begin{tabular}{|c|c|c|c|c|c|c|}
\hline Scale Item & Mean & SD & $\begin{array}{l}\text { SE of } \\
\text { mean }\end{array}$ & $\begin{array}{l}\text { Corrected item- } \\
\text { total correlation }\end{array}$ & $\begin{array}{c}\text { Alpha if item } \\
\text { deleted }\end{array}$ & $\begin{array}{c}\text { Cronbach alpha } \\
\text { of scale }\end{array}$ \\
\hline Aw1 & 4.92 & .276 & .021 & .619 & .714 & .797 \\
\hline Aw2 & 4.88 & .330 & .025 & .644 & .696 & \\
\hline Aw3 & 4.81 & .392 & .030 & .664 & .692 & \\
\hline Ass 1 & 4.65 & .646 & .050 & .489 & .772 & .797 \\
\hline Ass2 & 4.72 & .576 & .044 & .639 & .731 & \\
\hline Ass 3 & 4.59 & .630 & .048 & .656 & .721 & \\
\hline Ass 4 & 4.59 & .701 & .054 & .593 & .740 & \\
\hline Ass5 & 4.42 & .797 & .061 & .499 & .779 & \\
\hline PQ1 & 4.63 & .594 & .046 & .692 & .825 & .861 \\
\hline PQ2 & 4.56 & .705 & .054 & .706 & .822 & \\
\hline PQ3 & 4.59 & .684 & .052 & .682 & .828 & \\
\hline PQ4 & 4.61 & .557 & .043 & .679 & .830 & \\
\hline PQ5 & 4.51 & .557 & .043 & .636 & .839 & \\
\hline Lo1 & 4.76 & .465 & .036 & .660 & .729 & .808 \\
\hline Lo2 & 4.63 & .623 & .048 & .583 & .755 & \\
\hline Lo3 & 4.71 & .527 & .040 & .664 & .717 & \\
\hline Lo4 & 4.43 & .678 & .052 & .564 & .774 & \\
\hline PSR1 & 4.16 & .965 & .074 & .642 & .904 & .912 \\
\hline PSR2 & 4.22 & .945 & .072 & .711 & .900 & \\
\hline PSR3 & 4.27 & 1.013 & .078 & .570 & .907 & \\
\hline PSR4 & 4.01 & .948 & .073 & .627 & .904 & \\
\hline PSR5 & 4.27 & .966 & .074 & .560 & .908 & \\
\hline PSR6 & 4.09 & .940 & .072 & .746 & .898 & \\
\hline PSR7 & 4.38 & .883 & .068 & .587 & .906 & \\
\hline PSR8 & 4.06 & .844 & .065 & .745 & .899 & \\
\hline PSR9 & 4.15 & .908 & .070 & 619 & .905 & \\
\hline PSR10 & 4.02 & .945 & .072 & .723 & .900 & \\
\hline PSR11 & 4.37 & .776 & .059 & .632 & .904 & \\
\hline PSR12 & 4.44 & .729 & .056 & .615 & .905 & \\
\hline
\end{tabular}


TABLE 7

RELIABILITY OF SCC SCALE

\begin{tabular}{llllccc}
\hline Scale Item & Mean & SD & $\begin{array}{c}\text { SE of } \\
\text { mean }\end{array}$ & $\begin{array}{c}\text { Corrected item- } \\
\text { total correlation }\end{array}$ & $\begin{array}{c}\text { Alpha if item } \\
\text { deleted }\end{array}$ & $\begin{array}{c}\text { Coefficient } \\
\text { alpha of scale }\end{array}$ \\
\hline SCC1 & 4.49 & 1.084 & .083 & .378 & .750 & 0.768 \\
SCC2 & 4.13 & .914 & .070 & .318 & .755 & \\
SCC3 & 4.42 & 1.007 & .077 & .336 & .754 & \\
SCC4 & 4.50 & .931 & .071 & .493 & .735 & \\
SCC5 & 4.57 & .768 & .059 & .398 & .747 & \\
SCC6 & 4.42 & .782 & .060 & .483 & .738 & \\
SCC7 & 4.45 & .792 & .061 & .471 & .739 & \\
SCC8 & 4.26 & .927 & .071 & .468 & .738 & \\
SCC9 & 4.52 & .755 & .058 & .370 & .749 & \\
SCC10 & 4.38 & .857 & .066 & .337 & .753 & \\
SCC11 & 4.55 & .807 & .062 & .438 & .742 & \\
SCC12 & 4.42 & .941 & .072 & .336 & .754 & \\
\hline
\end{tabular}

The rewarding socially responsible brands (RSRB) scale achieved coefficient alpha values greater than 0.60 , which is lower than the value of 0.70 for good internal consistency (Nunnally, 1978). Column six in Table 8.0 indicates there will be no improvement in alpha with the deletion of any items, which indicates good consistency and content validity.

\section{TABLE 8 \\ RELIABILITY OF RSRB SCALE}

\begin{tabular}{ccccccc}
\hline $\begin{array}{c}\text { Scale of } \\
\text { Mean }\end{array}$ & Mean & SD & $\begin{array}{c}\text { SE of } \\
\text { mean }\end{array}$ & $\begin{array}{c}\text { Corrected Item- } \\
\text { Total correlation }\end{array}$ & $\begin{array}{c}\text { Alpha if } \\
\text { Item } \\
\text { deleted }\end{array}$ & $\begin{array}{c}\text { Coefficient } \\
\text { Alpha of } \\
\text { Scale }\end{array}$ \\
\hline RSRB1 & 3.05 & 1.178 & .090 & .353 & .581 & .636 \\
RSRB2 & 4.22 & 1.117 & .086 & .440 & .511 & Sig.049 \\
RSRB3 & 4.32 & 0.873 & .067 & .553 & .460 & \\
RSRB4 & 4.18 & 1.180 & .061 & .290 & .629 & \\
RSRB5 & 3.58 & 1.94 & .091 & .345 & .517 & \\
\hline
\end{tabular}

\section{Scale Validity and Content Validity}

To verify construct validity, the correlations pattern between the CBBE construct and its five firstorder components were explored. The EFA with the principal component analysis yielded a five-factors solution, which confirmed the dimensionality hypothesis. Table 8 reports the correlation between factors. The results show that all the five components have highly significant correlations, between the dimensions and CBBE construct, which indicates the existence of higher order constructs (Clark \& Watson, 1995). In addition, the higher values of the corrected item-total correlations and the coefficient alpha of the overall CBBE scale indicate convergent validity.

The five components share significant correlations with each other, except for awareness with loyalty and awareness with PSR. However, the correlations between the second-order CBBE construct and the five first-order components are much higher than the correlations between the five first-order components, which indicate divergent validity. By this it can be inferred that each of the five components 
captures some substantial and unique portion of the CBBE construct. Thus, this supports hypotheses H1 to H5.

\section{Nomological Validity}

For establishing nomological validity, the measure of the CBBE construct must show a significant and positive association with rewarding the brand for its social responsibility and ready to pay a price premium for perceiving such value. The result of the regressions analysis in

Table 9 provides evidence of nomological validity for the CBBE scale.

\section{FIGURE 1}

\section{RELATIONSHIP BETWEEN CONSUMER-BASED BRAND EQUITY AND THE OUTCOMES}

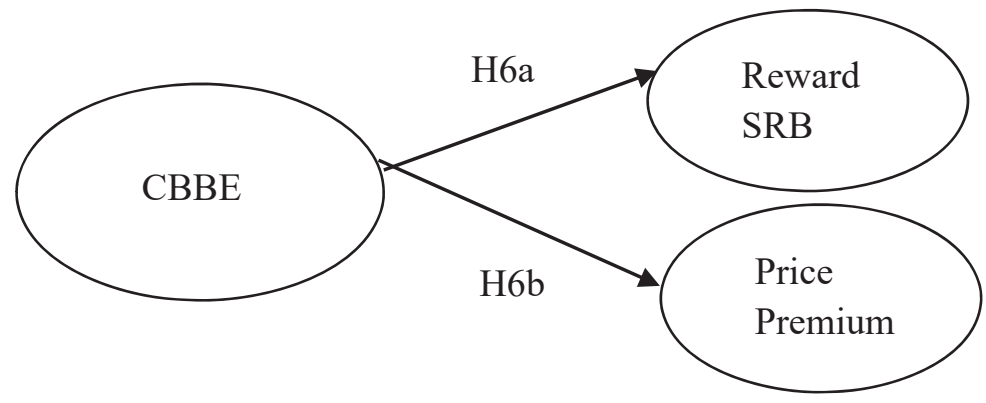

TABLE 9

HYPOTHESES TESTING

\begin{tabular}{llc}
\hline H No & Hypothesis & Supported \\
\hline H6a & $\begin{array}{l}\text { The higher the level of CBBE in consumers' minds, the higher will be the } \\
\text { intention to reward a social-responsible brand. }\end{array}$ & Yes \\
H6b & $\begin{array}{l}\text { The higher the level of CBBE in consumers' minds, the higher will be the } \\
\text { intention to pay a price premium to a socially responsible brand. }\end{array}$ & No \\
\hline
\end{tabular}

\section{TABLE 10 \\ RESULTS FROM THE REGRESSION ANALYSIS FOR CBBE AS INDEPENDENT VARIABLE}

\begin{tabular}{lcc}
\hline \multicolumn{1}{c}{ Statistics/dependent } & Rewarding SRB & Paying Price Premium \\
\hline Standardized regression coefficients at $\mathrm{p}<0.01$ & 0.610 & 0.395 \\
Standard errors & 0.094 & 0.159 \\
R Squares & 0.372 & 0.156 \\
\hline
\end{tabular}

The regression analysis reveals significant and positive associations of the CBBE construct with rewarding social responsibility of a brand (H6a), though it shows a positive relationship for paying a price premium for a socially responsible brand, it was not so positive. The standardized regression coefficients for both the hypothesized relationships are significant but are different in their magnitude. Thus, the results support hypothesis 6a. It was expected that a positive association exists between CBBE and paying a price premium to a brand's social responsibility. However, consumers are not ready to pay a higher price; this came as a counterintuitive result and requires further research on the issue, which has to be explored in the confirmatory research (see Figure 1). 


\section{Confirmatory Study and Scale Finalization}

The RSRB one-factor and two-factor model fit indices for both the milk and snacks category are provided in Table 10.1 and 10.2. The model fit indices GFI, NFI, CFI and TLI were all above 0.95 in both product categories. RMSEA was 0.018 and 0.053 in case of milk and snacks, respectively, which are within the limits of the recommended value, 0.08, by MacCallum et al., (1996), and 0.06 by $\mathrm{Hu}$ and Bentler (1999). The two-factor model provides a better fit (see Figure 2).

FIGURE 2

MEASUREMENT MODEL OF REWARDING SOCIAL RESPONSIBILITY OF THE BRAND

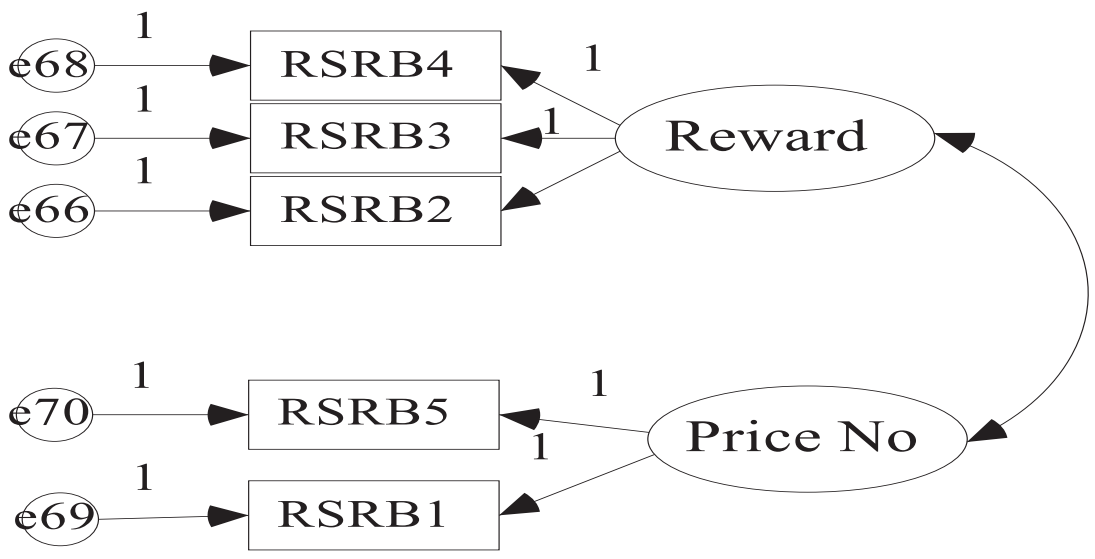

TABLE 10.1

ESTIMATES OF THE RSRB TWO FACTOR MODEL IN MILK CATEGORY

\begin{tabular}{rrlrrrrr}
\hline & & & Estimate & SRW & S.E. & C.R. & P \\
\hline C30 & $<---$ & Reward & 1.000 & 0.798 & & & \\
C31 & $<---$ & Reward & 1.100 & 0.845 & 0.052 & 21.291 & *** \\
C32 & $<---$ & Reward & 1.000 & 0.765 & & & \\
C33 & $<---$ & Price No & 1.000 & 0.838 & & & \\
C29 & $<---$ & Price No & 1.000 & 0.810 & & & \\
\hline
\end{tabular}

TABLE 10.2

ESTIMATES OF THE RSRB TWO FACTOR MODEL IN SNACKS CATEGORY

\begin{tabular}{rrlrrrrr}
\hline & & & Estimate & SRW & S.E. & C.R. & P \\
\hline C30 & $<---$ & Reward & 1.000 & 0.796 & & & \\
C31 & $<---$ & Reward & 0.949 & 0.747 & 0.051 & 18.699 & $* * *$ \\
C32 & $<---$ & Reward & 1.000 & 0.818 & & & \\
C33 & $<---$ & Price No & 1.000 & 0.757 & & & \\
C29 & $<---$ & Price No & 1.000 & 0.850 & & & \\
\hline
\end{tabular}


TABLE 10.3

FIT STATISTICS OF THE MEASUREMENT MODEL RSRB

\begin{tabular}{lccccccccc}
\hline Model & $\begin{array}{c}\text { Chi } \\
\text { Square: } \\
\text { Dof }\end{array}$ & $\begin{array}{c}\text { CMIN/ } \\
\text { Dof }\end{array}$ & $\begin{array}{c}\text { P } \\
\text { value }\end{array}$ & $\begin{array}{c}\text { GFI } \\
\text { Milk Product }\end{array}$ & $\begin{array}{c}\text { RMSEA: } \\
\text { PClose }\end{array}$ & NFI & CFI & TLI & Remarks \\
RSRB one factor & $274.492: 6$ & 45.749 & .000 & .855 & $.288: .000$ & .747 & .750 & .770 & Poor fit \\
RSRB two factor & $7.103: 6$ & 1.184 & .031 & .995 & $.018: .866$ & .993 & .999 & .998 & \\
Snack Product & & & & & & & & & \\
RSRB one factor & $147.564: 6$ & 24.594 & .000 & .899 & $.215: .000$ & .858 & .862 & .770 & Poor fit \\
RSRB two factor & $14.677: 6$ & 2.446 & .023 & .989 & $.053: .385$ & .986 & .992 & .986 & \\
\hline
\end{tabular}

\section{Socially Conscious Consumer (SCC) Scale}

In the confirmatory study, the entire sample of milk (541) and snacks (511) categories were combined for analysis. The poorly performing items, SCC 2, 3, 6, 8, 9, 10, 11 were identified and deleted from the scale. After the deletion of items, the trait model was re-estimated and re-analyzed to test the incremental fit of the model. The finalized scale consisted of five items, SCC 1, 4, 5, 7 and 12, which had a better fit (see Figure 3.0 for the measurement model). Table 11.1 contains the standardized factor loadings with critical ratios and significance levels and Table 11.2 gives the model fit indices. The model fit indices GFI, NFI, CFI and TLI were all above the recommended levels of 0.95 and RMSEA was 0.044 .

\section{FIGURE 3.0}

\section{MEASUREMENT MODEL OF SOCIALLY CONSCIOUS CONSUMER}

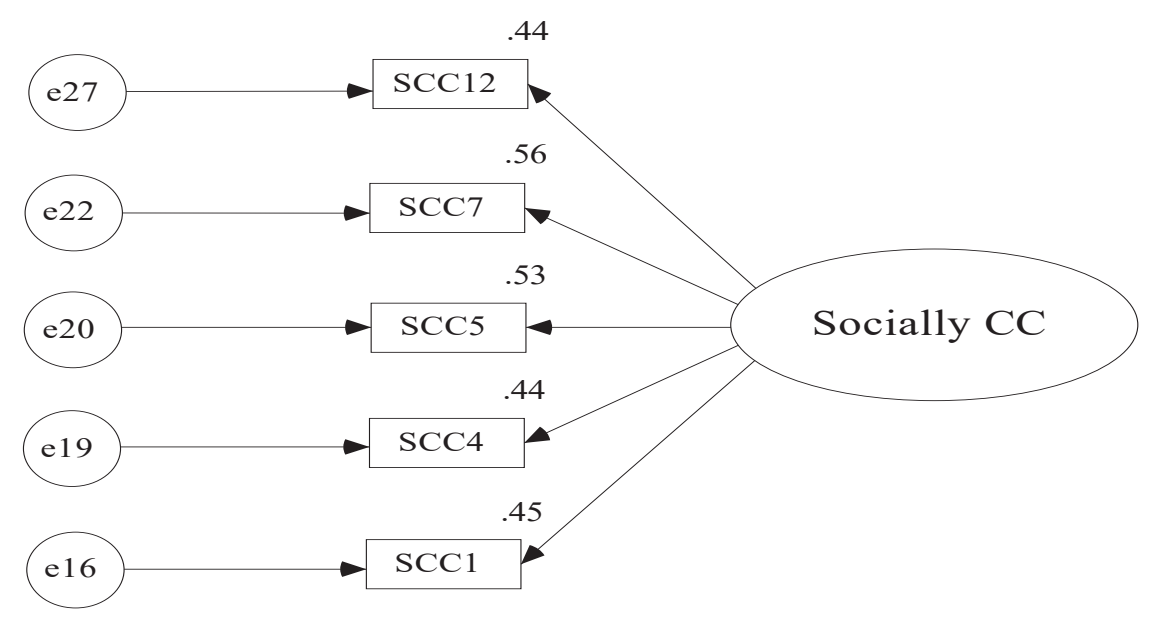


TABLE 11.1

ESTIMATES OF THE SCC FINALISED MODEL

\begin{tabular}{|c|c|c|c|c|c|c|c|}
\hline & & & Estimate & SRW & S.E. & C.R. & $\mathrm{P}$ \\
\hline B12 & $<---$ & Socially CC & 0.845 & 0.439 & 0.044 & 18.993 & $* * *$ \\
\hline B7 & $<---$ & Socially CC & 1.029 & 0.558 & 0.049 & 21.004 & $* * *$ \\
\hline B4 & $<---$ & Socially CC & 0.798 & 0.439 & 0.042 & 18.998 & $* * *$ \\
\hline B5 & $<---$ & Socially CC & 1.000 & 0.531 & & & \\
\hline B1 & $<---$ & Socially CC & 0.841 & 0.446 & 0.044 & 19.133 & $* * *$ \\
\hline
\end{tabular}

TABLE 11.2

FIT STATISTICS OF THE SCC MODEL

\begin{tabular}{|c|c|c|c|c|c|c|c|c|c|}
\hline Model & $\begin{array}{c}\text { Chi } \\
\text { Square: } \\
\text { DoF }\end{array}$ & $\begin{array}{c}\text { CMIN/ } \\
\text { DoF }\end{array}$ & $\begin{array}{c}\mathrm{P} \\
\text { value }\end{array}$ & GFI & $\begin{array}{l}\text { RMSEA: } \\
\text { PClose }\end{array}$ & HFI & CFI & TLI & Remarks \\
\hline $\begin{array}{l}\text { SCC } \\
\text { (preliminary) }\end{array}$ & 157.100:40 & 3.950 & .001 & .975 & $.053: .273$ & .940 & .954 & .924 & Poor fit \\
\hline SCC (finalised) & $10.572: 5$ & 2.114 & .061 & .996 & $.033: .832$ & .994 & .997 & .993 & \\
\hline
\end{tabular}

\section{Social Desirability (SD) Scale}

The original Marlow-Crowne Scale viewed social desirability as a single-factor construct. The subsequent research has viewed social desirability as a two-factor model comprising denial and attribution components (e.g., Millham, 1974; Ramanaiah, Schill, \& Leung, 1977; Ramanaiah \& Martin, 1980).

FIGURE 4.0

MEASUREMENT MODEL OF SOCIAL DESIRABILITY SCALE

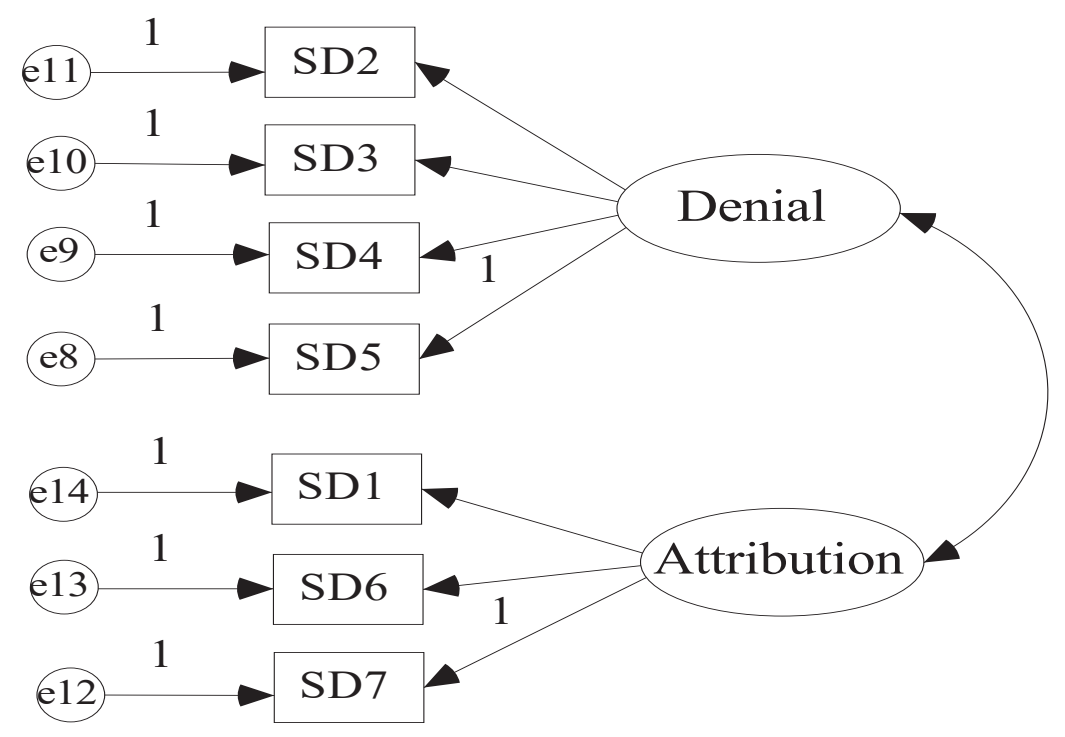

Of the seven items culled by Fischer and Fick (1993) from the original Marlowe-Crowne Social Desirability Scale (Crowne \& Marlowe, 1960), three items (item numbers 16, 26, and 33) from the 
original Marlowe-Crowne Scale loaded on to the attribution factor, and the remaining four items (item numbers $11,15,19,22)$ were loaded onto the denial factor as indicated by Loo and Thorpe (2000). The entire sample of milk (541) and snacks (511) categories was used for the analysis. The analysis was done with SD as one-factor and two-factor models.

\section{TABLE 12.1}

ESTIMATES OF THE SD TWO-FACTOR MODEL

\begin{tabular}{|c|c|c|c|c|c|c|c|}
\hline & & & Estimate & SRW & S.E. & C.R. & $\mathrm{P}$ \\
\hline E5 & $<---$ & Denial & 1.000 & 0.535 & & & \\
\hline E4 & $<---$ & Denial & 1.029 & 0.536 & 0.085 & 12.162 & $* * *$ \\
\hline E3 & $<---$ & Denial & 1.212 & 0.645 & 0.106 & 11.388 & $* * *$ \\
\hline E2 & $<---$ & Denial & 1.260 & 0.678 & 0.112 & 11.279 & $* * *$ \\
\hline E7 & $<---$ & Attribution & 1.000 & 0.393 & & & \\
\hline E6 & $<---$ & Attribution & 2.204 & 0.884 & 0.603 & 3.654 & $* * *$ \\
\hline E1 & $<---$ & Attribution & 0.838 & 0.371 & 0.083 & 10.143 & $* * *$ \\
\hline
\end{tabular}

Table 12.1 contains the standardized factor loadings with critical ratios and significance levels. The two-factor model (see Figure 4.0 for the measurement model) had a better fit compared to the one-factor model (see Table 12.2 for fit statistics). The model GFI was above 0.95 and RMSEA was 0.04 below the recommended level of 0.06 by $\mathrm{Hu}$ and Bentler (1999). NFI, CFI and TLI were above 0.90, though the indices are below the recommended levels of 0.95 and are better than the one-factor model. Hence, the two-factor model of the scale was considered to produce an acceptable fit compared to one-factor model of the data, supporting the arguments of Millham (1974), Ramanaiah et al., (1977), and Ramanaiah and Martin (1980).

TABLE 12.2

FIT STATISTICS OF THE SD TWO-FACTOR MODEL

\begin{tabular}{cccccccccc}
\hline Model & $\begin{array}{c}\text { Chi } \\
\text { Square: } \\
\text { DoF }\end{array}$ & $\begin{array}{c}\text { CMIN/ } \\
\text { DoF }\end{array}$ & $\begin{array}{c}\text { P } \\
\text { value }\end{array}$ & $\begin{array}{c}\text { GFI } \\
\text { RMSEA: } \\
\text { PClose }\end{array}$ & NFI & CFI & TLI & Remarks \\
\hline SD one factor & $465.732: 14$ & 33.267 & .001 & .876 & $.175: 000$ & .661 & .666 & .499 & Poor fit \\
SD two factor & $47.722: 10$ & 4.772 & .001 & .987 & $.060: .152$ & .965 & .972 & .941 & \\
\hline
\end{tabular}

\section{Measurement Model of the CBBE Construct}

The research has conceptualized $\mathrm{CBBE}$ as a reflective second-order construct having five first-order factors. The measurement model of the construct having 28 indicators from the preliminary scale was analyzed using CFA in Amos 18.0 software. The preliminary trait, measurement model of the construct, is represented in Figure 6.0, containing the standardized factor loadings and squared multiple correlations. 
TABLE 13.0

FIT STATISTICS OF THE MEASUREMENT MODELS OF CBBE

\begin{tabular}{|c|c|c|c|c|c|c|c|c|c|}
\hline Model & $\begin{array}{c}\text { Chi } \\
\text { Square: } \\
\text { DoF }\end{array}$ & CMIN & $\begin{array}{c}\mathrm{P} \\
\text { value }\end{array}$ & GFI & NFI & CFI & TLI & $\begin{array}{l}\text { RMSEA: } \\
\text { PCIOSE }\end{array}$ & ECVI; AIC \\
\hline $\begin{array}{l}\text { Preliminary Trait } \\
\text { Model Milk }\end{array}$ & $582.47: 337$ & 1.728 & .001 & .926 & .924 & .967 & .962 & $.037: 1.00$ & $1.334: 720.47$ \\
\hline $\begin{array}{l}\text { Preliminary Trait } \\
\text { Model Snacks }\end{array}$ & $843.10: 337$ & 2.502 & .001 & .892 & .852 & .905 & .893 & $.054: .062$ & $1.924: 981.10$ \\
\hline $\begin{array}{l}\text { Preliminary Trait } \\
\text { Model combined }\end{array}$ & $991.60: 337$ & 2.942 & .001 & .934 & .924 & .948 & .942 & $.043: 1.00$ & $1.075: 1129.6$ \\
\hline
\end{tabular}

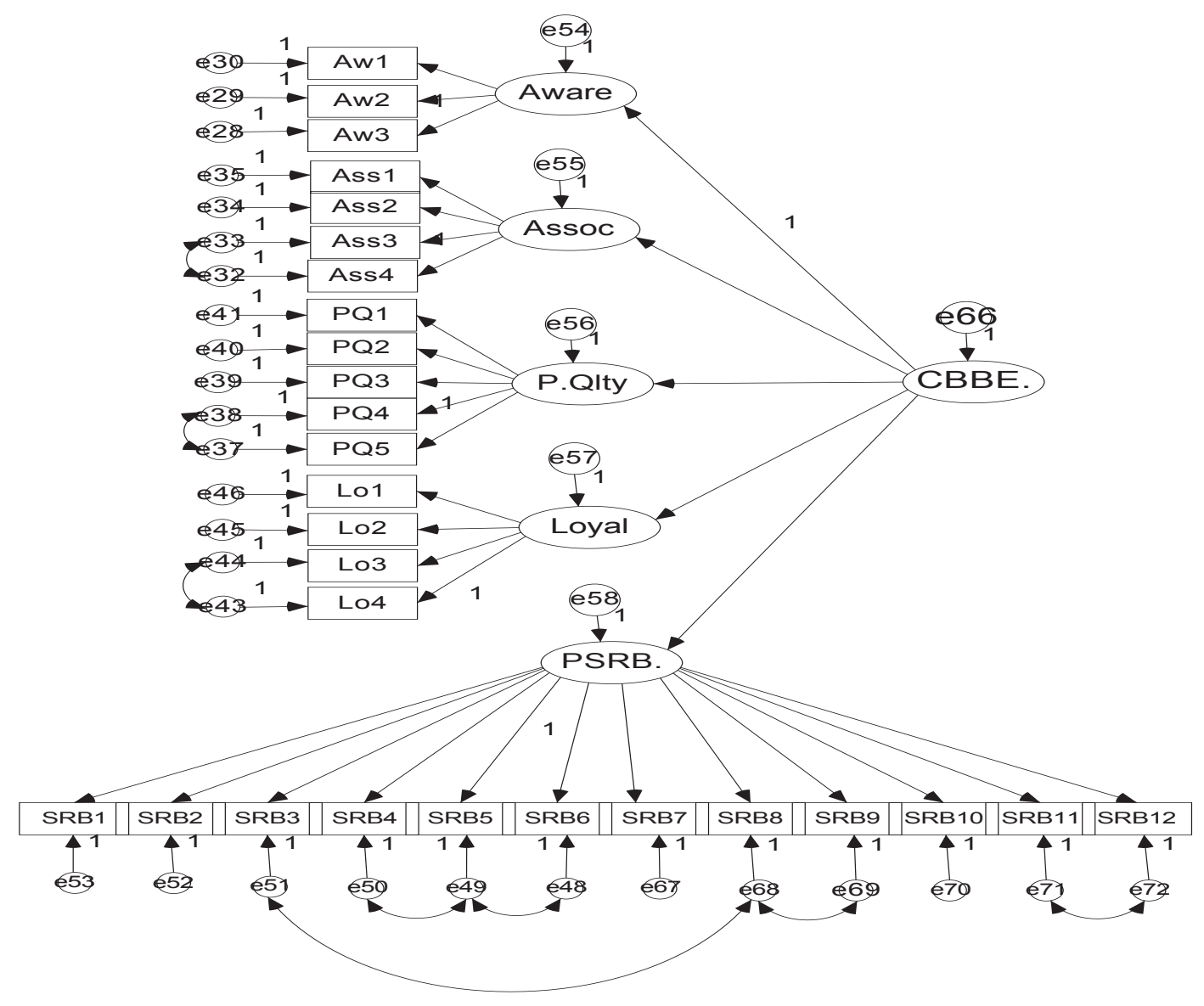

Chi-square indicates the overall fit of the model and "assesses the magnitude of discrepancy between the sample and the fitted covariances matrices" (Hu \& Bentler, 1999, p.2). The fit statistics CMIN value for the preliminary model of milk and snacks were 1.728 and 2.502 with a p value of .001, which indicates the model is statistically significant. The model fit indices for both milk and snacks (see Table 13) GFI, NFI, CFI and TLI were all above 0.95 and RMSEA was 0.31 , which is below the desired level of 0.05 (Hu \& Bentler, 1999). 


\section{DISCUSSION AND CONCLUSION}

Porter and Kramer (2006) observe that social responsibility has become an "inescapable priority" for firms. Over the years, CSR has emerged as a legitimate, and critical endeavor in marketing research (Gelb \& Strawser, 2001). The principle is that firms should contribute to the welfare of society.

Brand equity is associated with efficient marketing activities (Smith \& Park, 1992; Srivastava \& Shocker, 1991), and firm's decisions are often made based on the value of the brand to the customers. An understanding of this aspect of behavior helps the marketer to develop an appropriate marketing strategy. As Keller (1993) pointed out, a higher CBBE index can lead firms to generate higher revenue, and have the ability to implement a more effective marketing mix.

$\mathrm{CBBE}$ and social responsibility in particular has yet received much research attention. Researchers in the CBBE area have faced the lack of valid scales for measuring various constructs of interest. As a result, Keller (2003) expresses the acute need to enhance the measurement of CBBE. Additionally, the literature on $\mathrm{CBBE}$ shows that different components have been used by different studies, which indicates that $\mathrm{CBBE}$ is not static but dynamic. Thus, this conceptualization of CBBE with perceived social responsibility would pave the way to enhance the varied conceptualizations and operationalization of CBBE that exist in the literature. As such, the objective of this study was to construct a reliable, valid and parsimonious measure of CBBE with perceived social responsibility component. In doing so, this research adapts the established scales from previous studies to capture the dimensions such as awareness, association, perceived quality and loyalty. The finalized scale exhibits reasonable psychometric properties. Additionally, the scale was also tested for convergent, discriminant and nomological validities. In this process, the study extended the theory of CBBE in product categories of essential goods e.g., milk. We also found that consumers are interested in socially responsible brands but reluctant to pay premiums for such brands.

In conclusion, this study develops a new brand equity measurement and provides empirical evidence of the multidimensionality of CBBE. Yet, the results might vary for other products such as cars. Therefore, there may be a need to study the applicability of the scale to other product categories. In addition, we used a cross-sectional survey, which could not provide a longitudinal view of the phenomenon. Future research may use a longitudinal design to corroborate the causal influence of CBBE. Finally, it may be worthwhile to investigate the differences regarding the scale dimensions between developed and developing regions. 


\section{REFERENCES}

Aaker, D. A. (1991). Managing brand equity: Capitalizing on the value of a brand name. New York: Free Press.

Agarwal, M. K., \& Rao, V. R. (1996). An empirical comparison of consumer-based measures of brand equity. Marketing Letters, 7(3), 237-247.

Anderson, J. R. (1993). Rules of the mind. Hillsdale, NJ: Erlbaum.

Anderson, J. C., \& Gerbing, D. W. (1988). Structure equation modelling in practice: A review and recommended two-step approach. Psychological Bulletin, 103(3), 411-423.

Atilgan, E., Akinci, S., Aksoy, S., \& Kaynak, E. (2009). Customer-based brand equity for global brands: A multinational approach. Journal of Euromarketing, 18(2), 115-132.

Berry, L. (2000). Cultivating service brand equity. Journal of the Academy of Marketing Science, 28(1), 128-137.

Blumenthal, D., \& Bergstrom, A. J. (2003). Brand councils that care: Towards the convergence of branding and corporate social responsibility. Brand Management, 10(4), 327-341.

Bowen, J. T., \& Shoemaker, S. (1998). Loyalty: A strategic commitment. Cornell Hotel and Restaurant Administration Quarterly, 39(1), 12-25.

Brickley, J., Smith, C., \& Zimmerman, J. (2002). Business ethics and organizational architecture. Social Science Network Electronic Paper Collection, 250947.

Brown, T. J. (1998). Corporate associations in marketing: Antecedents and consequences. Corporate Reputation Review, 1, 215-233.

Brunso, K., Thomas, A. F., \& Grunert, G. K. (2002, June). Consumers' food choice and quality perception. Working Paper, 77, The Aarhus School of Business.

Buil, I., de Chernatony, L., \& Martinez, E. (2008). A cross-national validation of the consumer-based brand equity scale. Journal of Product and Brand Management, 17(6), 384-392.

Burns, A., \& Bush, R. (1998). Marketing Research. London: Prentice-Hall.

Chen, A. C. H. (2001). Using free association to examine the relationship between characteristics of brand associations and brand equity. Journal of Product and Brand Management, 10(7), 439-451.

Churchill, G. A., Jr. (1979). A paradigm for developing better measures of marketing constructs. Journal of Marketing Research, 16(16), 64-73.

Clark, L. A., \& Watson, D. (1995). Constructing validity: Basic issues in objective scale development. Psychological Assessment, 7, 309-319.

Christodoulides G., de Chernatony, L., Furrer, O., Shiu, E., \& Abimbola, T. (2006). Conceptualising and measuring the equity of online brands. Journal of Marketing Management, 22(7-8), 799-825.

Chu, S., \& Keh, H.T. (2006). Brand value creation: Analysis of the interbrand-Business Week brand value rankings. Marketing Letters, 17(4), 323-331.

Churchill, G. A., Jr. (1979, February). A paradigm for developing better measures of marketing constructs. Journal of Marketing Research, 16, 64-73.

Cobb-Walgren, C. J., Rule C. A., \& Donthu, N. (1995). Brand equity brand preference and purchase intent. Journal of Advertising, 24(3), 25-40.

Cohen, M. A., Fenn, S. A., \& Naimon, J. (1995). Environmental and financial performance: Are they related? Working Paper. Investor Responsibility Research Center: Washington, D.C.

Cooke, E. F., Rayburn, J. M., \& Abercrombie, C. L. (1992). The history of marketing thought as reflected in the definition of marketing. Journal of Marketing Theory and Practice, 1(1), 10-20.

Crimmins, J. C. (1992, July/August). Better measurement and management of brand value. Journal of Advertising Research, 32, 11-19.

Cronbach, L., \& Meehl, P. (1995). Construct validity in pyschological tests. Psychological Bulletin, 52(4), 281-302.

Crowne, D., \& Marlowe, D. (1960). A new scale of social desirability independent of psychopathology. Journal of Consulting Psychology, 24, 349-354. 
Cryer, E., \& Ross, W. (1997). The influence of firm behavior on purchase intention: Do consumers really care about business ethics? Journal of Consumer Marketing, 14(6), 421-433.

Deanna Wang, H. (2010). Corporate social performance and financial-based brand equity. Journal of Product \& Brand Management, 19(5), 335-345.

de Chernatony, L., Cottam, S., \& Segal-Horn, S. (2006). Communicating services brands values internally and externally. The Services Industries Journal, 26(8), 819-36.

De Pelsmacker, P., Driesen, L., \& Rayp, G. (2005). Do consumers care about ethics? Willingness to pay for fair-trade coffee. The Journal of Consumer Affairs, 39(2), 363-385.

Doyle, P. (1989). The brand in business: The strategic importance of brands. The Economic Conference Unit, London.

Drucker, P. J. (1958). Marketing and economic development. Journal of Marketing, Cambridge: University Press, 2.

Dunn, S. C., Seaker R. F., \& Waller M. A. (1994). Latent variables in business logistics research: Scale development and validation. Journal of Business Logistics, 15(2), 145-172.

Dutton, G. (1997). Warming the cold heart of business. Management Review, 86(6), 17-20.

Erdem, T., \& Swait, J. (1998). Brand equity as a signalling phenomenon. Journal of Consumer Psychology, 7(2), 131-157.

Erdem, T., Swait, J., \& Louviere, J. (2002). The impact of brand credibility on consumer price sensitivity. International Journal of Research in Marketing, 19(1), 1-19.

Farquhar, P. H. (1989). Managing brand equity. Marketing Research, 1, 24-33.

Fischer, D., \& Fick, C. (1993). Measuring social desirability: Short forms of the Marlowe-Crowne Social Desirability Scale. Educational and Psychological Measurement, 53, 417-424.

Fombrun, C., \& Shanley, M. (1990). What's in a name? Reputation building and corporate strategy. Academy of Management Journal, 33(2), 233-258.

Fornell, C., \& Larcker, D. F. (1981). Evaluating structure equation models with unobservable variables and measurement error. Journal of Marketing Research, 18(1), 39-50.

Fournier, S. (1998). Consumers and their brands: Developing relationship theory in consumer research. Journal of Consumer Research, 24(4), 343-373.

Ganster, D. C., Hennessey H. W., \& Luthans, F. (1983). Social desirability response effects: Three different models. Academy of Management Journal, 26(2), 955-966.

Garver, M. S., \& Mentzer, T. J. (1999). Logistics research methods: Employing structure equation modelling to test for construct validity. Journal of Business Logistics, 20, 1, 33-57.

Gelb, D. S., \& Strawser, J. A. (2001). Corporate social responsibility and financial disclosure: An alternative explanation for increased disclosure. Journal of Business Ethics, 33, 1-13.

Gerbing, D., \& Anderson, J. (1988). An updated paradigm for scale development incorporating unidimensionality and its assessment. Journal of Marketing Research, 25(2), 186-192.

Hair, J. F., Black, W. C., Babin, B. J., Anderson R. E., \& Tatham, R. L. (1998). Multivariate Data Analysis. New Jersey: Pearson Prentice Hall.

Hattie, J. (1985). Methodology review: assessing unidimensionality of tests and items. Applied Psychological Measurement, 9, 139-164.

Hsieh, Ming-Huei. (2004, Summer). Measuring global brand equity using cross-national survey data. Journal of International Marketing, 12, 28-57.

Hu, L.T., \& Bentler P.M. (1999). Cut off criteria for fit indexes in covariance structure analysis: Conventional criteria versus new alternatives. Structural Equation Modelling, 6, 1, 1-55.

Jaffe, A. B., Peterson., S. R., Portney, P. R., \& Stavins, R. N. (1995). Environmental regulation and the competitiveness of U.S. manufacturing: What does the evidence tell us? Journal of Economic Literature, 33, 132-163.

James, W. L., \& Sonner, B. S. (2001). Just say no to traditional student samples. Journal of Advertising Research, 41(5), 63-71.

Jensen, M. B., \& Klastrup, K. (2008). Towards a B2B customer-based brand equity model. Journal of Targeting, Measurement \& Analysis for Marketing, 16(2), 122-128. 
Jones, R. (2005). Finding sources of brand value: Developing a stakeholder model of brand equity. Brand Management, 13(1), 10-32.

Jöreskog, K. G. (1970). A general method for the analysis of the covariance structures. Biometricks, 57, 238-51.

Jourdan, P. (2002). Measuring brand equity: Proposal for conceptual and methodological improvements. Advances in Consumer Research, 29(1), 290-298.

Kapferer, J. N. (2004). The new strategic brand management. London: Kogan Page.

Kamakura, W. A., \& Russell, G. J. (1993). Measuring brand value with scanner data. International Journal for Research on Marketing, 10, 9-22.

Kayaman, R., \& Huseyin, A. (2007). Managing service customer-based brand equity - evidence from the hotel industry. Managing Service Quality, 17(1), 92-109.

Keller, K. L. (1993). Conceptualizing, measuring and managing customer-based brand equity. Journal of Marketing, 57, 1-22.

Keller, K. L. (1998). Strategic brand management: Building, measuring and managing brand equity. New Jersey: Prentice Hall.

Kim, J., Forsythe, S., Gu, Q., \& Moon, S. J. (2002). Cross-cultural consumer values, needs and purchase behaviour. The Journal of Consumer Marketing, 19(6), 481-502.

Kim, W. G., Jin-Sun, B., \& Kim, H. J. (2008). Multidimensional consumer-based brand equity and its consequences in mid-priced hotels. Journal of Hospitality and Tourism Research, 32, 235-254.

Klein, J., \& Dawar, N. (2004). Corporate social responsibility and consumers' attributions and brand evaluations in a product-harm crisis. International Journal of Research in Marketing, 21, 203 217.

Koçak, A., Abimbola, T., \& Ozer, A. (2007). Consumer brand equity in a cross-cultural replication: An evaluation of a scale. Journal of Marketing Management, 23(1/2), 157-173.

Kotler, P. (1991). Marketing management: Analysis, planning, implementation, and control (7th edition). Prentice Hall: Upper Saddle River, NJ.

Kraft, K. L., \& Singhapakdi, A. (1991). The role of ethics and social responsibility in achieving organizational effectiveness: Students versus managers. Journal of Business Ethics, 10, 679-686.

Lai, C-S., Chiu, C-J., Yang, C-F., \& Pai, D-C. (2010). The Effects of corporate social responsibility on brand performance: The mediating effect of industrial brand equity and corporate reputation. Journal of Business Ethics, 95(3), 457-469.

Lassar, W., Mittal, B., \& Sharma, A. (1995). Measuring customer-based brand equity. Journal of Consumer Marketing, 12(4), 11-19.

Laurent, G., \& Kapferer, J. (1985). Measuring consumer involvement profiles. Journal of Marketing Research, 22, 41-53.

Leuthesser, L., Kohli, C. S., \& Harich, K. R. (1995). Brand equity: The halo effect measure. European Journal of Marketing, 29(4), 57-66.

Levy, S. J. (1999). Brands, consumers, symbols, \& research: On marketing. Thousand Oaks, CA: Sage Publications.

Levitt, T. (1960). Marketing myopia. Harvard Business Review, 38, 45-56.

Lichtenstein, D. R., Drumwright, M. E., \& Braig, B. M. (2004). The effect of corporate social responsibility on customer donations to corporate-supported nonprofits. Journal of Marketing, 68(10), 16-33.

Loo, R., \& Thorpe, K. (2000). Confirmatory factor analysis of the full and short versions of the MarloweCrowne Social Desirability Scale. The Journal of Social Psychology, 140(5), 628-635.

Low, G. S., \& Lamb, C. W., Jr. (2000). The measurement and dimensionality of brand associations. The Journal of Product and Brand Management, 9(6), 350-370.

Luo, X., \& Bhattacharya, C. B. (2006, October). Corporate social responsibility, customer satisfaction, and market value. Journal of Marketing, 70, 1-18.

Mackay, M. M. (2001). Evaluation of brand equity measures: Further empirical results. The Journal of Product and Brand Management, 10(1), 38.

90 Journal of Applied Business and Economics Vol. 22(1) 2020 
MacCallum, R. C., Browne, M. W., \& Sugawara, H. M. (1996). Power analysis and determination of sample size for covariance structure modelling. Psychological Methods, 1(2), 130-49.

Madrigal, R. (2000). The role of corporate associations in new product evaluation. Advances in Consumer Research, 27.

McCarthy, E. J., \& Perreault, W. D., Jr. (1993). Basic marketing: A global-managerial approach. Homewood, IL: Irwin.

McDonald, R. P. (1981). The dimensionality of tests and items. British Journal of Mathematical and Statistical Psychology, 34, 110-117.

Millham, J. (1974). Two components of need for approval score and their relationships to cheating following success and failure. Journal of Research in Personality, 8, 378-392.

Mitchell, A. A., \& Dacin, A. P. (1996, December). The assessment of alternative measures of consumer expertise. Journal of Consumer Research, 23, 219-239.

Mitra, D., \& Ghosh, A. (2007, July-September). Creation of an effective brand image: A few steps, brand marketing practices in India. The Indian Journal of Commerce, 60(3), 63.

Mizik, N., \& Jacobson, R. (2008). The financial value impact of perceptual brand attributes. Journal of Marketing Research, 45(1), 15-32.

Morton, J. (1994). Predicating brand preference, Marketing Management, 2(4), 32-44.

Park, C. S., \& Srinivasan, V. (1994). A survey-based method for measuring and understanding brand. Journal of Marketing Research, 31(92), 271-288.

Swait, J., Erdem, T., Louviere, J., \& Dubelaar, C. (1993, March). The equalization price: A measure of consumer-perceived brand equity. International Journal of Research in Marketing, 10, 23-45.

Varadarajan, P. R., \& Menon, A. (1988, July). Cause-related marketing: A coalignment of marketing strategy and corporate philanthropy. Journal of Marketing, 52, 58-74. 